\title{
Enunciaciones heterogéneas en la poesía indígena actual de Chile y Perú*
}

\author{
Heterogeneous enunciations in the current aboriginal poetry of Chile and Peru
}

\author{
Claudia Rodríguez Monarca \\ Universidad Austral de Chile, Instituto de Lingüística y Literatura, Valdivia, Chile, \\ e-mail: claudiar@uach.cl
}

En el repertorio de la poesía hispanoamericana actual uno de los elementos de interés es el resituamiento de la poesía indígena (mapuche, quechua o aymara en este caso) que, sin abandonar su eje de reflexión identitaria, se desplaza hacia otras preocupaciones intertextuales, interculturales, interdisciplinarias y transdiscursivas, que hibridan sus textos con otras tradiciones literarias y manifestaciones discursivas. Las principales disciplinas que se detectan en cruce son las artes visuales, la música y la historiografía, algunas de ellas bajo la modalidad de intertextos transliterarios o claves metatextuales. El corpus considera a César Millahueique, Juan Paulo Wirimilla (Chile), José Luis Ayala y Odi Gonzales (Perú), poetas que tienen como denominador común la experiencia compartida no sólo de ser sujetos migrantes sino de ser "letrados". El sujeto enunciador es heterogéneo y responde a su realidad y condición intercultural; sin embargo, a pesar de su competencia bilingüe y bicultural no logra integrarse. La presencia de múltiples voces se revela en los textos tanto bajo la forma de polifonía, es decir varias voces, varios sujetos, como de esquizofrenia, varias voces en un mismo sujeto.

Palabras clave: postvanguardia, enunciación heterogénea, sujeto migrante, transdiscursividad.

One of the remarkable aspects of the present Hispanic-American poetry is the repositioning of the aboriginal poetry (Mapuche, Quechua, or Aymara in this case) which, without leaving the perspective of its identity reflection, moves the attention to focuses of intertextual, intercultural, interdisciplinary and transdiscursive interest. This, in turn, results in hybrid texts related with other literary traditions and discursive expressions. The main disciplines detected in this hybridization process are the visual arts, music and historiography, some of them in the form of transliterary intertexts or metatextual keys. The corpus includes several poets such as César Millahueique, Juan Paulo Wirimilla (Chile), José Luis Ayala and Odi Gonzales (Perú), who share not only the experience of being migrants but also their literacy condition. The enunciators are heterogeneous, and are a result of their own reality and intercultural condition; although, in spite of their bilingual and bicultural skills they don't reach full integration. The existence of multiple voices is revealed in the texts both under the form of polyphony, that is, several voices, several characters, and schizophrenia, several voices in the same character.

Key words: postvanguard, heterogeneous enunciation, migrants, transdiscursivity.

\footnotetext{
* Una primera versión de este trabajo fue leída en el XV Congreso Internacional de la Sociedad Chilena de Estudios Literarios (SOCHEL), en Temuco, en mayo del 2008, y forma parte del proyecto Fondecyt $\mathrm{N}^{\mathrm{o}} 1070208$ (Conicyt), "Mutaciones y migraciones en la literatura hispanoamericana del cono sur (19602000)", investigador responsable: Oscar Galindo V.
} 


\section{INTRODUCCIÓN}

En el marco de la poesía hispanoamericana encontramos la poesía indígena contemporánea, que no se subsume o asimila al repertorio mayor, sino que comparte ciertos rasgos y estrategias discursivas y textuales, y, al mismo tiempo, aporta y enriquece el sistema literario desde sus particularidades, especialmente desde enunciaciones heterogéneas, biculturales y bilingües. Interesa para estos efectos revisar el proceso de resituamiento de la poesía indígena que, sin abandonar su eje de reflexión identitaria, se desplaza hacia otras preocupaciones intertextuales, interculturales e interdisciplinarias y transdiscursivas hibridando sus textos con otras tradiciones literarias, estéticas y culturales. Este aspecto, propio de los elementos más innovadores de la poesía indígena, es parte de los complejos trazados del cuestionamiento de saberes y disciplinas que han contribuido a un proceso de transformación de la poesía hispanoamericana contemporánea. La crisis, ampliación y modificación del sistema literario provoca una imagen de dispersión y caoticidad, como resultado fundamentalmente de migraciones e hibridajes interdisciplinarios e interartísticos. Ello nos coloca ante un escenario polidimensional que ha provocado, en sus dimensiones más innovadoras, fronteras caracterizadas por asimilaciones y mutaciones disciplinarias (Carrasco 2002, 2003; Galindo 2002, 2004), afectando los límites de las literaturas y de otras disciplinas. A estos procesos, y precisamente por su condición fronteriza, no ha estado ajena la poesía indígena.

Iván Carrasco (2005) ha señalado que la poesía etnocultural ha modificado y ampliado el canon literario chileno ${ }^{1}$. En una línea similar Fierro y Geeregat se han referido al paso ("evolución") de la literatura mapuche a la literatura chilena, entendiendo la asunción de los propios poetas mapuches como poetas insertos en el circuito literario hegemónico. Si la propuesta teórico-crítica de la poesía etnocultural ha permitido instalar la discusión y reflexión de esta literatura fronteriza en el contexto de la literatura chilena, en el caso de Perú encontramos aportes ensayísticos y enfoques críticos que ponen especial énfasis en aquellas literaturas que se gestan en el marco y el contexto de sociedades marginadas culturalmente (Rodríguez, 2005). Así se acuñan nociones como "literatura escrita alternativa" de Martín Lienhard (1992), “otra literatura" de Edmundo Bendezú $(1980,1986)$ al hablar de la literatura peruana, especialmente en lengua quechua de la cual es traductor; y "literaturas heterogéneas" de Antonio Cornejo Polar (1978, 1994), quien introduce esta categoría para referirse a las literaturas peruanas, criticando la supuesta "unidad" de una literatura nacional que excluye a las literaturas indígenas y populares.

Como hemos explicado en trabajos anteriores a propósito de la poesía mapuche (Rodríguez 2006), el complejo y dificultoso proceso de incorporación de la poesía indígena a los sistemas literarios nacionales ha estado mediatizado por los debates en torno a la conformación de las identidades nacionales. Así ante la idea dominante

\footnotetext{
1 "La literatura marginal, secundaria o alternativa conforma una zona invisibilizada comparativamente menor en cantidad y heterogénea en su conformación (...). Los textos interculturales constituyen la variedad más singular y definida de la asimilación, adecuación y transformación de la literatura canónica europea en las élites culturales de Chile y América Latina y, al mismo tiempo, de la reacción contra la imposición de modelos culturales, lingüísticos y textuales" (Carrasco 2005).
} 
de nación monocultural, se ha ido imponiendo el concepto de estado pluriétnico, e imbricadamente ha ocurrido un proceso de incorporación de literaturas "marginales" al canon literario, entre las que tienen especial relevancia las literaturas indígenas. Sin embargo, esta discusión ha estado también sesgada por las expectativas culturales dominantes que esperan de los escritores de las llamadas culturas originarias, un repertorio de temáticas preferentemente identitarias, así como el reprocesamiento literario de géneros y recursos poéticos provenientes de la oralidad y la ritualidad. Por lo mismo, el sistema poético indígena se encuentra en una frontera cultural (Lotman, 1996) con distintos grados de interferencia: interacción, diálogo y conflicto con el polisistema literario dominante. Even Zohar (1999) ha señalado, como un elemento adicional, que la edad de un sistema puede ser también un factor decisivo respecto a la selección de las estrategias de elaboración, adopción y préstamo que deben tomarse para que el sistema funcione. Cuando el sistema es "joven" su repertorio suele ser más limitado en la disponibilidad de recursos del repertorio, lo que le da una mayor disposición para usar otros sistemas disponibles (p.e. otras lenguas, otras culturas, otras literaturas, otras artes). En el caso de la escritura de poetas indígenas chilenos y peruanos se advierte un sistema permeable, abierto a la incorporación de recursos provenientes de otras artes, de otras literaturas y de otras tradiciones. Por lo mismo, suele ser frecuente la adopción de estrategias escriturales vanguardistas o de avanzada, lo que provoca expresiones discursivas, genéricas y estéticas de carácter mutante. Los textos suelen ser híbridos desde el punto de vista lingüístico (doble codificación), cultural (collages etnoculturales) y artístico (mutaciones disciplinarias y genéricas). Paul Guillén (2006) ha señalado que es necesario adscribir y abrir nuevas posibilidades de lectura de los sistemas literarios desde la poesía "culta" o "trascendentalista" hasta la poesía popular o la escrita en quechua o aymara. Hay que considerar, en su opinión, que el Perú (pero bien puede ampliarse esta hipótesis para el caso chileno) posee una tradición multicultural con fuertes expresiones de sincretismo no resuelto o de bilingüismo cultural. Presencia de una poesía ágrafa y de una poesía escrita, sistemas que conviven y tienen relación cada uno con el otro. Por ello, una de las confusiones habituales es referirse de manera indistinta a los poetas indígenas y a los cantores de sus propias tradiciones indígenas en sus lenguas vernáculas. Se trata en rigor de sistemas que tienen interrelaciones evidentes (como lo tiene la poesía en castellano con su tradición oral), pero que pertenecen en la actualidad a ámbitos estéticos diferentes.

Queda en evidencia, de esta manera, que se amplía el polisistema literario latinoamericano con la incorporación y reconocimiento del repertorio indígena, no sólo de textos y autores, sino de modelos de texto que aportan nuevas estrategias discursivas, textualidades y reflexiones identitarias. Nuestra hipótesis es que la construcción enunciativa en este tipo de textos se caracteriza por su condición heterogénea, rasgo que afecta tanto a los sujetos como al enunciado poético. El corpus literario considera a César Millahueique y Juan Pablo Wirimilla (Chile) y José Luis Ayala y Odi Gonzales (Perú). 


\section{Sujeto MigRANTE, LETRADO Y ORAL}

"He vuelto padre, soy letrado, libre vengo de orgullos y exageraciones, pues aunque mis manos se nutrieron de vocales, las estrellas a años luz de nuestro pan/ quedaron mudas..."

Elicura Chihuailaf

¿Qué pueden tener en común autores como Millahueique, Wirimilla, Gonzales o Ayala? Son indígenas y son escritores. Podemos señalar también que son parte de la "diáspora indígena" (mapuche, quechua, aymara); translocación territorial, simbólica e idiomática, como han señalado Fierro y Geeregat (2004) a propósito de la poesía mapuche, o sujetos migrantes, al decir de Cornejo Polar (1996). Las migraciones desde el campo a la ciudad, que luego han traspasado las fronteras nacionales, llevaron a este crítico a establecer la categoría de sujeto migrante para dar cuenta literariamente de esta condición ${ }^{2}$, a través de un proceso por el cual el sujeto va conformando un discurso descentrado, heterogéneo, múltiple, que enuncia y traduce una biculturalidad con elementos antagónicos que no se resuelven ni sincrética ni sintéticamente (como sí lo hace la categoría de mestizaje), sino evidencia la tensión no zanjada, la "totalidad contradictoria", las experiencias "dispersas, quebradizas, inestables y heteróclitas"3, lo que llevará a algunos críticos a postular incluso que estos sujetos comienzan a presentar rasgos esquizoides o sicóticos. Tendrán como común denominador los poetas del corpus la experiencia compartida no sólo de ser sujetos migrantes, y experimentar esta condición desterritorializada de la migrancia (Mazzotti 2002), sino de ser "sujetos letrados".

El mismo acto de migrar hace que el sujeto se conforme internamente heterogéneo.

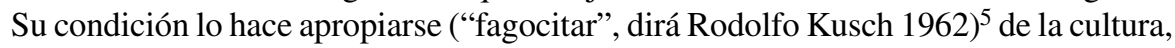
la escritura y lengua ajenas, lo que posibilita que el migrante reconvierta sus saberes y producciones en el ámbito urbano (Canclini 1990), de manera multidireccional y como estrategia de resistencia, de defensa (sin diluir sus diferencias y problemas, sino acentuándolos) y de compensación y redención (Noriega 1993a; 1993b). Esto permite, según la poeta mapuche Adriana Paredes Pinda (2008), reconstituir un territorio que, si no ancestral directamente, les afiata sus referentes identitarios, vinculándolos en

\footnotetext{
2 Arguedas es considerado "el fundador de la poética quechua migrante" para Julio Noriega (1996), quien analiza la migración del serrano a partir de la música y la poesía.

${ }^{3}$ El discurso del migrante para Cornejo Polar "es radicalmente descentrado, en cuanto se construye alrededor de ejes varios y asimétricos, de alguna manera incompatibles y contradictorios de un modo no dialéctico. Imagino que el allá y el aquí, que son también el ayer y el hoy, refuerzan su aptitud enunciativa y pueden tramar narrativas bifrontes (...) considero que el desplazamiento migratorio duplica (o más) el territorio del sujeto y le ofrece o lo condena a hablar desde más de un lugar. Es un discurso doble o múltiplemente situado" (1996: 841).

${ }^{4}$ Esta nueva condición, sin embargo, no era privilegio de sus antepasados, pues muchos indígenas fueron perseguidos y amenazados por querer "estudiar". Como versaba un dicho popular desde la época de la Colonia, "indio leído, indio perdido".

5 "El mundo indígena ha sido sometido, pero, al mismo tiempo, ha conseguido «fagocitar» al mundo occidental para revelar el verdadero ser americano; fagocitación o absorción de las pulcras cosas de Occidente por las cosas de América, como a modo de equilibrio o reintegración de lo humano en estas tierras" (Kusch 1962: 17).
} 
forma permanente a su imaginario, a su memoria colectiva y a sus orígenes e identidades territoriales. En una línea similar, pero a propósito de la literatura andina, Julio Noriega $(1995,1996)$ va a señalar que el sujeto migrante, hablando desde un universo escindido, no sólo se reincorpora al espacio sacralizado de su origen en un viaje imaginario a través de la lengua y de la memoria, sino que en un "discurso mítico-utópico" va de la resistencia a la subversión, de la despedida a la reconquista, del desarraigo al retorno mítico. Se escenifica así el testimonio de la destrucción violenta de dos mundos, en este caso del tradicional andino y del moderno urbano. Para este crítico se realiza genuinamente como el esfuerzo utópico por reconstruirlos en una dimensión verdaderamente universal: humana y divina al mismo tiempo (1996: 330).

Los sujetos migrantes irrumpen en la ciudad letrada (al decir de Rama 1984; Mazzotti 2002) y esa pluralidad va a permitir cuestionar el modelo radical de cultura; ciudad escrituraria (Bueno 1996), centrada y excluyente. Se torna necesario indagar qué ocurre con esa producción textual (estas "imágenes de la inclusión") tanto en el mundo indígena como en las culturas dominantes (Espino 1999). La "ciudad oral" avanza sobre la nación letrada apelando al reconocimiento de su existencia e interrogando la hegemonía del centro. El asalto, el asedio, a la ciudad letrada, continúa Bueno, lo es también a las instituciones literarias, una vez que buscan establecer otros códigos, nuevos registros donde reconocerse, utilizando el testimonio como único género disponible para su inserción en los márgenes del canon literario, ejerciendo lo que Rama denominó "plasticidad cultural" (1982). Vinculamos estas nociones a la de "aldea letrada quechua" (Espino 2002, 2007), esa suerte de tránsito y retorno entre oralidad y escritura quechua y la compleja relación con el mundo de la ciudad letrada y canónica.

Retomemos la pregunta inicial: ¿Qué pueden tener en común autores como Millahueique, Wirimilla, Ayala o Gonzales? Son "letrados", profesionales graduados y postgraduados en la educación "formal", con una alta cuota de competencia multicultural y literaria (pensemos en los paratextos de Wirimilla citando a Borges, José Emilio Pacheco o Vallejo, o a José Luis Ayala aludiendo a catorce artistas, entre ellos Roque Dalton, Gioconda Belli, Carlos Condorena). Manejan más de un registro lingüístico: Odi Gonzales estudió su postgrado en EE.UU. y habla quechua, castellano e inglés; José Luis Ayala Olazával (Huancané, Puno 1942) es yatiri, adivino, vivió en Francia y habla francés, castellano y aymara, además de empaparse de las vanguardias europeas; ambos escriben en versiones trilingües. En el caso de Millahueique (actor, gestor público y doctorando en arquitectura) y Wirimilla (profesor y crítico literario), si bien no son hablantes nativos, hacen el guiño en sus textos al mapudungun a través del collage etnolingüístico.

\section{ENUNCIACIONES HETEROGÉNEAS: POLIFONÍA Y ESQUIZOFRENIA}

La categoría de enunciación heterogénea ${ }^{6}$ nos permite reconocer la presencia de sujetos cuyo posicionamiento intercultural no resuelto establece una condición

\footnotetext{
${ }^{6}$ En el campo de la teoría etnocultural, Iván Carrasco propone la estrategia de la "enunciación sincrética", entendida como el modo propio de expresión de los textos de doble codificación que caracterizan la poesía mapuche: "La enunciación de los textos de doble codificación es el resultado de la mezcla de categorías y
} 
ambivalente, desde el punto de vista lingüístico y cultural. La instancia de producción del enunciado permite incorporar distintos hablantes, saberes y modos de expresión como el relato o el testimonio. El sujeto enunciador heterogéneo responde a su realidad y condición intercultural, y a pesar de su competencia bilingüe y bicultural no logra integrarse, hacer una síntesis, sino que opta por una de sus herencias o por evidenciar esa tensión no resuelta. La presencia de múltiples voces las podemos detectar en los textos tanto bajo la forma de polifonía, es decir varias voces, varios sujetos; o de esquizofrenia, varias voces en un mismo sujeto.

La polifonía es la pluralidad de voces que se corresponden con múltiples conciencias independientes e inconfundibles no reductibles entre sí. Por tanto, cada voz enunciativa es sujeto de su discurso y no solo objeto del discurso. En la Escuela de Cusco de Odi Gonzales el propio autor ha señalado que lo que lo motiva de la escuela cusqueña son:

Los maestros indígenas de la Escuela que llegaron a reproducir espléndidamente el brillo de la lágrima de un arcángel o los ojos acuosos de Mamacha Belén; sin embargo, ellos -por desconocer los códigos de la escritura- no pudieron dibujar las letras de su propio nombre, razón por la que no pudieron firmar sus trabajos, permaneciendo anónimos o con nombres genéricos como "El anónimo de Maras", "El maestro de Chinchero", etc. En este libro yo quise devolverles la voz a estos magníficos pintores (Chirinos 2005).

Los sujetos son múltiples, se asumen distintas voces: las de los pintureros que son los aprendices indígenas cusqueños y analfabetos que no pueden estampar su nombre en los cuadros ("el pintor/ que firmaba sus cuadros/ con un pajarito", página 39); la de los pintores maestros italianos y letrados, la de los sacerdotes, del XVI y XVII, la de los personajes de los cuadros; y también se cuela la voz del poeta (actual) y la de una especie de curador (identificable por el recurso de la letra cursiva), a veces crítico, irónico, otras informativo, descriptivo, con comentarios del contexto de producción.

Las voces a veces no sólo son distintas sino disímiles, tal es el caso de las voces de los pintureros versus los pintores. ¿Qué hay detrás de cada una de esas voces? Lo mismo que detrás del trazo, del pincel, el discurso del subalterno, pero también la "treta del débil", la marca, el sello, la impronta local y racial (lo mismo que en Vírgenes urbanas). El primer texto es "La última cena. Catedral del Cusco", lienzo famoso porque incluye en la mesa bíblica alimentos andinos: papaya, rocoto y hasta un cuy guisado. Reconoce el artista anónimo en los versos de Gonzales:

\author{
El lienzo \\ salió de mi mano: yo \\ pinté, doré y estofé la Santa Cena
}

\footnotetext{
elementos etnoculturales incorporados en la instancia de emisión y recepción. El hablante de estos textos, por lo general un sujeto singular ubicado en la perspectiva de su propia cultura, asume el saber de su grupo étnico, pero también el de aquel con el que se conecta o sobre el que habla. Al mismo tiempo, incorpora en el acto comunicativo que efectúa el saber de la instancia de recepción, conformada en forma dual o plural a través del doble registro o del collage. Resulta evidente que el destinatario de un texto en doble código es, lógicamente, también doble, debido al uso de códigos lingüísticos diferentes" (1991: 13).
} 
Pero esa voz se presenta en contrapunto con otra que parece representar la voz del sujeto curador que "describe" la pintura, utilizando el recurso de la ironía:

Aquí

el taimado pintor indio...

en un rapto delirante

añadió por cuenta propia

potajes y viandas de su cosecha.

Hay dos tipos más de voces presentes en los poemas, una identificable con la del autor de los poemas y otra con la de los personajes representados en las pinturas:

Soy el arcángel apócrifo

soy el paria al que los legos llaman

Angel y príncipe del granizo

Mención aparte merecen los intertextos que se intercalan, como las referencias bíblicas. Gonzales no intenta reproducir con esta polifonía la estética manierista de la escuela cusqueña; más bien opta por un lenguaje simple y coloquial. Con estos recursos se logra una reflexión poética sobre la identidad peruana partiendo de su origen, el encuentro y la fusión entre lo andino y lo europeo. Un sincretismo, o hibridismo a veces, comprobado en estos cuadros de motivos católicos: “... el Edén abunda en árboles de kiswar / hordas de loros y flores de ñukchu...”.

El discurso esquizoide; a propósito del sujeto migrante comentamos las experiencias "dispersas, quebradizas, inestables y heteróclitas" propias de la incorporación imposible a la vida urbana. Es el caso del sujeto enunciante en Profecía en blanco y negro (1996), de César Millahueique, texto que se construye desde las múltiples voces de un sujeto chamánico en la ciudad: el machi, un sujeto lésbico, los mass media y el propio narrador, capaz de desdoblarse e interpretar a muchos otros. Como señala Adriana Paredes Pinda (2008) en uno de los trabajos más completos que existen sobre Millahueique: "En Profecía... estamos frente a un texto alucinatorio, caótico y fragmentario, que da cuenta a retazos de la vida de un sujeto lírico, cuyo reverso lésbico lo configura como una unidad inestable, indeterminada y periférica, tanto en relación a la sociedad urbana que lo succiona como ante la sociedad mapuche tradicional que vagamente rememora".

El sujeto de Profecía... puede ser esquizoide o neurótico desde la mirada winka, pero se trata en verdad de un sujeto migrante mapuche, sometido a las condiciones de espacios opresivos, urbanos, electrónicos, artificiales, no naturales, no reales. Sujeto antiheroico, antiprofético, antiutópico, destruido por los repertorios de uso de una sociedad mutiladora; en definitiva, "un sujeto posiblemente chamánico que ha transgredido su propio espíritu por no encontrar referentes legítimos ante su kutran o enfermedad mapuche" (Paredes Pinda 2008). El sujeto se predispone al ejercicio de sentirse un sobreviviente (un lli-tuche) al experimentar, en el tiempo de lo cotidiano, esta brutal condición desterritorializada de la migrancia, que intenta esquivar en el tiempo de la memoria. 


\section{MigraCión Y MUTACIÓN DISCIPLINARIA}

Migración (Cornejo Polar 1996), mutación disciplinaria (Carrasco 2002; Galindo 2002, 2004), discursos fronterizos (Galván 2002), literaturas postautónomas o escrituras diaspóricas (Ludmer 2006), transgresiones genéricas o géneros híbridos, parecieran ser estrategias que apuntan a una propuesta innovadora en el campo de los discursos literarios contemporáneos. Para Galindo (2004) la poesía hispanoamericana desde mediados del siglo XX hasta nuestros días ofrece como uno de sus rasgos constitutivos más interesantes un complejo proceso de mutaciones disciplinarias. Este proceso es resultado de la incorporación al canon poético de recursos de producción y estrategias discursivas provenientes de otras disciplinas, preferentemente de las llamadas ciencias sociales (sociología, antropología, historiografía). Galindo ha señalado que con estos procedimientos emerge un realismo de nuevo cuño que reprocesa el realismo tradicional por medio de nuevas formas de representación y de testimonialidad poéticas. Según Carrasco (2002), se trata de un nuevo tipo de género discursivo, de carácter híbrido; modalidad textual específica surgida en el conjunto de las posibilidades abiertas por la interdisciplinariedad en el discurso contemporáneo.

Sin embargo, este tipo de texto caracterizado por la heterogeneidad, confluencia o mezcla de géneros, contenidos y procedimientos de diversas disciplinas artísticas, ha sido el escenario y el modo en como se han manifestado los pueblos indígenas desde la época precolombina. Basta recordar como muestra la compleja obra Ollantay (que conjuga danza, teatro, canto y ritualidad), a la que se ha simplificado como "drama", o los cantos náhuatl que al ser transcritos se los cataloga como poemas. Ha resultado engorroso, también, clasificar muchos de esos textos principalmente porque temáticamente son híbridos como Los libros del Chilam Balam. Otro caso de construcción heterogénea es el que encontramos en los primeros cronistas mestizos o indígenas, habitantes de ambas culturas, como los Comentarios Reales del Inca Garcilaso de la Vega o la Nueva Corónica y Buen Gobierno de Guamán Poma de Ayala, en el que se articulan códigos visuales, literarios y cronísticos. Los poetas indígenas contemporáneos, "letrados", adscritos al circuito occidental, retomarán esta vertiente de textualidad multifacética, influenciados además por nuevas corrientes literarias en las cuales se han formado, particularmente con la tradición vanguardista y neovanguardista.

El acercamiento de ambos sistemas literarios ha permitido revitalizar una dupla presente ya en los primeros contactos de ambas tradiciones, lo que en su momento Cynthia Vich (2000) denominó, para el caso peruano, como "vanguardia nativista"7 a propósito de un estudio sobre el Boletín Titikaka (2000) que fija la atención, entre otros aspectos, en la preocupación por la valoración de las lenguas quechua y aymara.

\footnotetext{
7 Cynthia Vich (2000) en Indigenismo de vanguardia en el Perú: Un estudio sobre el Boletín Titikaka discute temas como la búsqueda y la definición de la identidad nacional y latinoamericana, la reivindicación del hombre y de la cultura del Ande, el surgimiento de una «vanguardia nativista» fuera de las tradicionales áreas urbanas de poder, el desarrollo de una novedosa poética y los proyectos pedagógicos orientados a reformar el sistema educativo de los indígenas y la valoración de las lenguas quechua y aymara.
} 


\section{Poesía, ARTES VISUALES, MÚSICA y CINE: DisCiPLinAS DE CRUCE}

Para ver cómo operan estas disciplinas en el texto es necesario considerar al libro como una unidad, un proyecto, una macronarración trazada a partir de una enunciación heterogénea. Muchos de los poemarios articulan una multiplicidad de voces, pinturas y escrituras que el poeta reescribe, describe, glosa, actualiza, provocando contrapuntos, superposición de voces, lenguas (diglosia) y registros, tras la compleja misión de desmontar no sólo los discursos poéticos, sino también los discursos oficiales hegemónicos de la historiografía, a través de nuevos mecanismos de representación y referencialidad. Las principales disciplinas que detectamos en cruce en el corpus de textos son las artes visuales, la música y el cine, algunas de ellas bajo la forma de intertextos transliterarios o claves metatextuales.

\subsection{LAS ARTES VISUALES}

Cuatro son las modalidades con las cuales esta disciplina se actualiza en los textos poéticos: a) a través de la pintura, con el recurso de la écfrasis; b) la fotografía, más específicamente el fotomontaje; c) el retrato y la ilustración, como complemento del texto poético base, y d) la imagen poética como figura retórica.

a) La Pintura: de la imagen a la escritura. En La Escuela de Cusco (2005), de Odi Gonzales, una serie de pinturas de origen colonial se convierten en un pretexto para reflexionar sobre la realidad y la historia peruanas, recreando lo que él llama la "atmósfera de resistencia cultural o subversión pictórica que los pintores erigieron cinco siglos atrás". Propone el autor una relectura de la evangelización ${ }^{8}$, a partir del diálogo con las obras de artistas, "pintureros" de la escuela formada el XVI por artistas europeos, principalmente italianos (Bitti y Medoro) para que ayuden, con sus cuadros, en el proceso de evangelización de los indios ${ }^{9}$. En estas "escuelas" los aprendices eran muchas veces los propios indígenas. Las pinturas de la Escuela Cusqueña revelan una peculiar iconografía, ya no perteneciente a una estética exclusivamente europea, sino influenciada por un particular mestizaje e hibridaje cultural, tensionado entre la evangelización española y la reacción, igualmente fervorosa, de los artistas indígenas. Estos poemas de cuadros ausentes también ceden la palabra a los pintureros y a sus protagonistas. Divididos en tres secciones (Pintureros, Museo de Indias y La Sixtina de América), los poemas del libro están inspirados en cuadros específicos, de los que toman el título. La estrategia que utiliza Gonzales es la descripción de estos cuadros a través de la écfrasis, esto es, la representación verbal/literaria de una obra plástica, con el fin de despertar en el receptor la imagen del objeto ausente; un texto de tema plástico que debiera reproducir lo más ajustada y fielmente posible esa plasticidad visible. Sin embargo, en algunos poemas Gonzales opta por enfatizar

\footnotetext{
8 "los lienzos me han servido sólo como referentes o pretextos para recrear desde el siglo XXI esa atmósfera de resistencia cultural o subversión pictórica que los pintores erigieron 5 siglos atrás. Así, los poemas no son descripciones de los cuadros; hay lienzos que no he vuelto a ver desde que tenía 6 ó 7 años. En este caso los lienzos son prescindibles". Entrevista realizada a Odi Gonzales por Roxana Chirinos (2005).

9 Como Diego Quispe Tito, Basilio Santa Cruz Pumaqallo, Antonio Sinchi Roca y una serie de pintores anónimos.
} 
sólo un detalle del lienzo ("Botas romanas, faldellín/ capa volante// sobre mi escudo rige/ un tordo ermitaño, 2005: 15), particularmente si éste es un elemento cultural o natural indígena, como resistencia a la evangelización de rasgos occidentales ("En la copa del Arbol Prohibido/ ¿lúcumo/ chirimoya?/ anida una wallata/ o ganso de los Andes"; 2005: 28).

b) La fotografía: imagen y escritura. Virgenes urbanas (2006) reúne el trabajo artístico de la fotógrafa Ana Orbegoso y del poeta Odi Gonzales. Tiene dos soportes distintos, uno que fue la muestra callejera de las fotografías de gran formato y otro que es un "libro-catálogo", un volumen que reúne fotos trabajadas con técnica digital sobre pinturas coloniales, que logran como resultado un collage, en conjunto con los textos poéticos -para cada una de las obras-, dándole voz a los personajes en tres idiomas: quechua, español e inglés. Este trabajo usa como imagen de fondo pinturas de la Virgen del período colonial, que son intervenidas, montadas con fotos contemporáneas de niños y mujeres del Perú actual. Con ello se modifica el objetivo inicial de esas pinturas para resignificarlas: la apropiación del pasado para convertirlo en presente y generar una mirada distinta, que invite a una reflexión identitaria.

c) El Retrato y la Ilustración: discursos complementarios. Tanto en Celebración cósmica de Rita Puma (2005) como en Wari Nayra/ Ojo de Vicuña (1999), de José Luis Ayala, encontramos el trazo del lápiz que acompaña, tímidamente, a la palabra poética. En el primero un retrato de Rita Puma, la joven líder aymara asesinada que actuó en la revolución de 1923, que abre el libro (entendido como una compleja unidad textual) y una de las múltiples estrategias testimoniales de representación a las que recurre el autor, junto con otras fuentes documentales (de las pocas rescatadas) y procedimientos propios del campo de las ciencias sociales, como las entrevistas y el trabajo etnográfico. Rita Puma es retratada y reconstruida a partir de diversos testimonios orales, ya que no hay ningún registro, visual o textual, de ella. En Wari Nayra/ Ojo de Vicuña se incorporan paralelamente ilustraciones del reconocido pintor surrealista de Trujillo, Gerardo Chávez. En el libro encontramos dibujos rupestres, imágenes de animales, recurrencias a máquinas, especialmente con ruedas, como patines y bicicletas, manchas y dibujos tétricos. Para Mario Vargas Llosa (1978) sus monstruos y personajes son "los actores de la gran fábula que es la vida para el autor". En su obra los personajes presentes transitan entre el pasado y lo imaginario. Crea una forma propia, que se reitera en las distintas criaturas que emanan del mito precolombino, de lo chamánico, de la cultura de su pueblo, al norte del Perú. Al igual que otros miembros de su generación, se erige como un punto de contacto entre el mestizaje indígena y la tradición europea. Chávez, a su manera, acompaña e interpreta el texto de Ayala, pero a su vez las ilustraciones constituyen un relato independiente.

d) Imagen poética (visiones): de la escritura a la imagen. Imágenes del rito (2006) de César Millahueique, es un texto hermético, complejo, híbrido en su constitución, la primera parte es prosa y la conforman siete textos, número simbólico y ritual para la cultura mapuche. Son textos sin título, sólo enumerados, como la sucesión de los escalones del rehue. La segunda parte la conforman 18 poemas. Todo el texto está cruzado, sin embargo, por la imagen, como recurso retórico y estrategia discursiva. La escritura conlleva una carga icónica, no puede dejar de leerse sin una apropiación 
visual, sin "ver" esas imágenes. En ellas se asumen las distintas voces de pueblos indígenas del continente, del pasado y del presente, casi como un trance chamánico, un "vuelo" que posibilita ver y estar en los distintos ritos y participar de las visiones del sujeto: "he tenido muchas visiones-dije- pero ésta es la más terrible, como un atardecer en un espejo quebrado. El coronel Urrutia navegando hacia la rivera del río Toltén. Hacia los llanos de Putue... instalándose en el Villarrica" (2006: 22). Sugerentes son los títulos de los poemas en verso, que remiten a este carácter visual: "Autorretrato del hombre entumecido", "Visiones", "Rostro de mujer extraña", "Jardín botánico", entre otros.

\subsection{MUSICA Y CINE}

Ambas disciplinas aparece con fuerza en estos textos poéticos bajo la forma de lo multimodal, lo sonoro y la imagen en movimiento, a través del recurso de la alusión y la cita.

El ojo de vidrio de Juan Paulo Wirimilla se construye a partir de la referencia cinematográfica y musical a "El Ojo de Vidrio", película ranchera sobre la revolución zapatista, estrenada en $1967^{10}$. En este caso Antonio Aguilar, actor y cantante mexicano, es Porfirio Buenavista y lidera una pandilla compuesta por sus cuatro primos. Su patrón le sacó un ojo en castigo por rebelarse, lo que aumenta su sed de venganza. Se une a la revolución, donde vive diversas aventuras, una de ellas lo lleva a conocer a "la Coralillo", dama que lo acompañará y será motivo del enternecimiento de su corazón. La banda sonora de la película, vigente aún, está compuesta por una gama de corridos que siguen escuchándose en localidades campesinas del Chile sureño.

$\mathrm{El}$ poemario recurre a la intertextualidad transliteraria al incorporar alusiones, glosas y citas de corridos y rancheras mexicanas. Como señala el propio Wirimilla, se trata de un género musical y popular instalado ya en la cultura mapuche y que reemplazaría al neneulun o elegía de hombre. La música popular, la ranchera, es el telón de fondo de El ojo de vidrio que reproduce la historia de un cuatrero. El hablante del texto de Wirimilla inicia su intervención con una referencia narrativa y musical a la vez: "Voy a contarle el corrido del salteador de caminos". Va a "relatar" una historia, pero además una historia con tono de ranchera o corrido mexicano, recreando el entorno en que suceden los hechos: caballos, pistolas, bares, caminos de tierra.

\section{CONClusiones: El ESCENARIO DE UNA POSIBLE POSTVANGUARDia POÉTICA INDÍGENA, ¿UN NUEVO “REALISMO”?}

Cuando se habla de las transformaciones de los textos poéticos indígenas, se piensa, principalmente, en la adquisición de la escritura, de la lengua castellana, de la entrada en el circuito literario y de las estrategias etnoculturales. Este discurso ha permitido explicar complejos fenómenos y procesos de producción literaria en contextos

\footnotetext{
${ }^{10}$ Un exhaustivo trabajo sobre este texto es el de Pamela Cárcamo "El original y su reflejo en El Ojo de vidrio de Juan Paulo Wirimilla", ponencia leída en Las Jornadas de Lengua y Literatura Mapuche 2008, Temuco.
} 
interculturales. ${ }^{11}$ Pero ¿dónde radica hoy lo nuevo "de lo nuevo" de esta producción? Pensamos que en su carácter de discurso mutante y migrante, esto es, caracterizado por la incorporación de estrategias heterogéneas de enunciación y representación y la ampliación del repertorio a través de nuevos soportes que superan el concepto de libro, como el catálogo y la instalación callejera de Vírgenes urbanas.

A modo de conclusión se puede insistir en que todas estas estrategias textuales y discursivas tienen como finalidad última la difícil misión de desmontar las tretas del fuerte. Como ha planteado Josefina Ludmer (2006), a propósito de su concepto de literaturas postautónomas, "las escrituras diaspóricas del presente no solo atraviesan la frontera de "la literatura" sino también la de "la ficción" [y quedan afuera-adentro]. Y esto ocurre porque reformulan la categoría de realidad: “....no se las puede leer como mero "realismo", en relaciones referenciales o verosimilizantes. Estas escrituras salen de la literatura y entran a "la realidad" y a lo cotidiano, a la realidad de lo cotidiano [y lo cotidiano es la TV y los medios, los blogs, el email, internet, etc]. Y toman la forma de escrituras de lo real: del testimonio, la autobiografía, el reportaje periodístico, la crónica, el diario íntimo, y hasta de la etnografía" (Ludmer, 2006).

Este trabajo es una invitación a repensar desde la crítica las transformaciones y mutaciones textuales y discursivas del polisistema literario hispanoamericano y la locación dentro de éste del repertorio de la poesía indígena hispanoamericana y de las redes y circuitos de comunicación que ya operan entre los poetas indígenas del continente.

\section{OBRAS CITADAS}

Ayala, José Luis. 1999. Wari Nayra/ Ojo de Vicuña. Perú: Editorial Horizonte.

—. 2005. Celebración cósmica de Rita Puma. Perú: Editorial San Marcos.

Bendezú, Edmundo. 1980. Literatura Quechua. España: Galaxis. Serie Biblioteca Ayacucho. 1986. La otra literatura peruana. México: Fondo de Cultura Económica.

Bueno Chávez, Raúl. 1996. Sobre la heterogeneidad literaria y cultural de América Latina. En Asedios a la heterogeneidad cultural. Homenaje a Antonio Cornejo Polar. José Antonio Mazzotti y U. Juan Cevallos, coordinadores. Asociación Internacional de Peruanistas. USA.

Cárcamo, Pamela. 2008. "El original y su reflejo en El Ojo de vidrio de Juan Paulo Wirimilla", ponencia leída en Las Jornadas de Lengua y Literatura mapuche en Temuco.

Carrasco, Iván. 1991. "Los textos de doble codificación. Fundamentos para una investigación”. Estudios Filológicos 26: 5-15.

—. 2002. "Interdisciplinariedad, interculturalidad y canon en la poesía chilena e hispanoamericana actual. Estudios Filológicos 37: 199-210.

—. 2003. "La antropología poética como mutación disciplinaria". Estudios Filológicos 38: 7-17.

11 Para Geeregat y Fierro (2002): "Los poetas mapuches irrumpen en la tradición del canon poético-literario chileno con una actitud transgresora y una estética compleja, lo que produce contradicciones radicales con las formas discursivas imperantes al recibir éstas el impacto de lo que significan los textos de "doble codificación", entendidos como tipos de discursos bilingües, mapudungun-español, o verdaderos complejos textuales caracterizados por su naturaleza etnocultural y que brotan de la interacción de culturas indígenas, criollas y extranjeras". 
—_. 2005. "Literatura chilena: canonización e identidades". Estudios Filológicos 40: 29-48.

Cornejo Polar, Antonio. 1978. "El indigenismo y las literaturas heterogéneas: Su doble estatuto sociocultural”. Revista de Crítica Latinoamericana 7-8: 7-21.

1982. Sobre literatura y crítica latinoamericanas. Venezuela: Ediciones de la Facultad de Humanidades y Educación, Universidad Central de Venezuela.

—. 1994: Escribir en el aire. Ensayos sobre la heterogeneidad sociocultural en las literaturas andinas. Lima, Ed. Horizonte.

— 1996. "Una heterogeneidad no dialéctica: Sujeto y discurso migrantes en el Perú moderno". Revista Iberoamericana vol. LXII: 837-844.

Chirinos, Roxana. 2005. Entrevista a Odi Gonzales, "La oralidad quechua contiene una notable sabiduría popular". Sección "Conversaciones", en agenciaperu.com

Espino Relucé, Gonzalo. 1999. Imágenes de la inclusión andina. Literatura peruana del XIX. Lima, Instituto de Investigaciones Humanísticas - Universidad Nacional Mayor de San Marcos.

. 2001. "La aldea letrada quechua: La literatura quechua en el espacio de la literatura canónica del siglo XIX", en Escritura y Pensamiento año IV, No 8, Revista del Instituto de Investigaciones Humanísticas, Lima; pp. 101-114.

—. 2007. Etnopoética quechua. Textos y tradición oral quechua. Lima, Universidad Nacional Mayor de San Marcos - Escuela de Postgrado (Tesis Doctoral en Literatura Peruana y Latinoamericana).

Even-Zohar, Itamar. 1999. "Factores y dependencias en la cultura. Una revisión de la Teoría de los Polisistemas". Teoría de los polisistemas (Estudio y compilación M. Iglesias Santos). Madrid: Arco/Libros: 23-52.

Fierro, J. M. y Geeregat, O. 2004. "La memoria de la Madre Tierra: el canto ecológico de los poetas mapuches". Anales de Literatura Hispanoamericana 33: 77-84.

Galindo, Oscar. 2002. "Mutaciones disciplinarias en la poesía de Enrique Lihn". Estudios Filológicos 37: 225-240.

—. 2004. "Interdisciplinariedades en las poesías chilena e hispanoamericana actuales". Estudios Filológicos 39: 155-165.

Galván, Verónica. 2002. "Discursos fronterizos", en Diálogos Latinoamericanos N ${ }^{\circ}$ 6: 21-31.

García Canclini, Néstor. 1990. Culturas híbridas. Estrategias para entrar y salir de la modernidad. México, Grijalbo.

Geeregat, Orietta V. y Fierro, Juan Manuel. 2002. “Testimonios poéticos del mestizaje mapuche. Memoria y contramemoria en textos de Elicura Chihuailaf, Leonel Lienlaf, Jaime Huenun y Bernardo Colipán", en Revista Razón y palabra, Número 26. (Revista electrónica).

Gonzales, Odi. 2005. La escuela de cusco. Lima: Santo Oficio.

- 2006. Vírgenes urbanas (fotografías de Ana de Orbegoso y poemas de Odi Gonzales).

Guillén, Paul. 2006. "Un espejo convexo: dos imágenes alternas en la poesía peruana de la década del 70 y 80". Galerna, Revista Internacional de Literatura 4: 132-144.

Kusch, Rodolfo. 1962. América Profunda. Buenos Aires: Hachette.

Lienhard, Martín. 1992. La Voz y su Huella: Escritura y conflicto étnico-cultural en América Latina 1492-1988. $3^{\mathrm{a}}$ aumentada. Perú: Editorial Horizonte.

Ludmer, Josefina. 2006. "Literaturas postautónomas de hoy". Instituto Tecnológico de Monterrey, sede México DF. Semana de las Humanidades. Conferencia 16 de octubre de 2006.

Mazzotti, J. Antonio. 2002. Poéticas del flujo: migración y violencia verbales en el Perú de los 80. Lima: Fondo Editorial del Congreso del Perú.

Millahueique, César. 1996. Profecía en Blanco y Negro. O las 125 líneas de un vuelo. Santiago: Talleres Gráficos El Arte. 
2006. Imágenes del rito. Santiago: Mosquito Comunicaciones.

Noriega, Julio. 1993a). "La Moderna poesía quechua escrita: una literatura de compensación y redención"; en Memorias JALLA. La Paz: Plural Editores - UMSA. Colección Academia $\mathrm{N}^{\circ} 3$ : 535-552.

—. 1993b). Poesía quechua escrita en el Perú. Antología. Lima: CEP.

—. 1995. Buscando una tradición poética quechua en el Perú. Miami: Centro Norte-Sur.

—. 1996. "La poética quechua del migrante andino", en Asedios a la heterogeneidad cultural. José Antonio Mazzotti e Ulises Juan Zevallos Aguilar (coordinadores). Philadelphia: Asociación Internacional de Peruanistas.

Paredes Pinda, Adriana. 2008. Heterogeneidad e hibridismo cultural en la poesía de César Millahueique. Tesis de Magíster en Literatura Hispanoamericana Contemporánea. UACh.

Rama, Angel. 1982. Transculturación narrativa en América Latina. México: Siglo Veintiuno. 1984. La ciudad letrada. Hannover: Norte.

Rodríguez, Claudia. 2005. "Las 'otras literaturas' de Latinoamérica. Criterios de inclusión y exclusión en el canon literario". Documentos Lingüísticos y Literarios 28: 77-81.

—. 2006. "Poesía Mapuche actual: repertorios en coexistencia e interferencia". Crítica hispánica vol. 28, № 1: 15-30.

Vargas Llosa, Mario. 1978. Presentación del Catálogo de la exposición Chávez en la galería Camino Brent, Lima.

Vich, Cynthia. 2000. Indigenismo de Vanguardia en el Perú: un estudio sobre El Boletín Titikaka. Lima: Editorial Fondo Ed. Pucp.

Wirimilla, Juan Paulo. 2002. El ojo de vidrio. Secretaría Regional Ministerial de Educación. 